\title{
Divergence and genetic variability among superior rubber tree genotypes
}

\author{
Lígia Regina Lima Gouvêa(1), Alisson Fernando Chiorato(2), Paulo de Souza Gonçalves ${ }^{(1)}$
}

\begin{abstract}
(1)Instituto Agronômico (IAC), Programa Seringueira, Caixa Postal 28, Cep 13001-970 Campinas, SP, Brazil. E-mail: Igouvea@iac.sp.gov.br, paulog@iac.sp.gov.br ${ }^{(2)}$ IAC, Centro de Pesquisa e Desenvolvimento de Recursos Genéticos Vegetais. E-mail: afchiorato@iac.sp.gov.br
\end{abstract}

\begin{abstract}
The objective of this work was to estimate the genetic variability and divergence among 22 superior rubber tree (Hevea sp.) genotypes of the IAC 400 series. Univariate and multivariate analyses were performed using eight quantitative traits (descriptors), including yield. In the univariate analyses, the estimated parameters were: genetic and environmental variances; genetic and environmental coefficients of variation; and the variation index. The Mahalanobis generalized distance, the Tocher agglomerative method and canonical variables were used for the multivariate analyses. In the univariate analyses, variability was verified among the genotypes for all the variables evaluated. The Tocher method grouped the genotypes into 11 clusters of dissimilarity. The first four canonical variables explained $87.93 \%$ of the cumulative variation. The highest genetic variability was found in rubber yield-related traits, which contributed the most to the genetic divergence. The most divergent pairs of genotypes are suggested for crossbreeding. The genotypes evaluated are suitable for breeding and may be used to continue the IAC rubber tree breeding program.
\end{abstract}

Index terms: Hevea brasiliensis, crossbreeding, multivariate analysis, selection.

\section{Divergência e variabilidade genética de genótipos superiores de seringueira}

\begin{abstract}
Resumo - $\mathrm{O}$ objetivo deste trabalho foi estimar a divergência e a variabilidade genética entre 22 genótipos superiores de seringueira (Hevea sp.) da série IAC 400. Análises univariadas e multivariadas foram realizadas com oito caracteres quantitativos (descritores), incluindo produtividade. Na análise univariada, os parâmetros estimados foram: variâncias genética e ambiental, coeficientes de variação genética e ambiental, e índice de variação. A distância generalizada de Mahalanobis, o método aglomerativo de Tocher e variáveis canônicas foram utilizados nas análises multivariadas. Nas análises univariadas, verificou-se variabilidade entre os genótipos para todas as variáveis avaliadas. O método de Tocher agrupou os genótipos em 11 grupos de dissimilaridade. As quatro primeiras variáveis canônicas explicaram $87,93 \%$ da variação acumulada. A maior variabilidade genética foi encontrada em variáveis relacionadas à produtividade de borracha, que foram as que mais contribuíram para a divergência genética. Os pares de genótipos identificados como mais divergentes são indicados para cruzamentos. Os genótipos avaliados são adequados para o melhoramento genético e podem ser utilizados para continuar o programa de melhoramento da seringueira do IAC.
\end{abstract}

Termos para indexação: Hevea brasiliensis, cruzamentos, análise multivariada, seleção.

\section{Introduction}

Hevea brasiliensis (Willd. ex A. Juss.) Müll. Arg. is an important industrial tree crop, grown mainly in the tropics, between latitude $12^{\circ}$, on either side of the Equator. It is the main source of natural rubber, used in the manufacture of thousands of products of which the pneumatic tire is the most popular (Chandrasekhar et al., 2007). According to data from the International Rubber Study Group -(International Rubber Study Group, 2009), 79\% of the world's natural rubber comes from Thailand (30\%), Indonesia (28\%) and Malaysia
(11\%), while Brazil contributes with only around $1 \%$ of the production.

To improve the productivity of rubber tree plantations, Hevea breeding programs exploit genetically variable populations to obtain superior trees (Gonçalves et al., 2006a). In Brazil, the main goal of the genetic breeding program for rubber tree developed at Instituto Agronômico (IAC) is to increase rubber yield and vigor. In this program, Hevea genotypes, from Asia and Africa, and Brazilian genotypes have been used in crossbreeding. Considering the wide range of crossbreeding possibilities, the selection of parental 
genotypes is a major concern in order to guarantee the best combinations. The selection of divergent parents is an option to restrict the number of crossings that permit finding genetic recombinations for superior hybrids in the segregating progeny.

The use of established multivariate statistical algorithms is an important strategy for classifying germplasm, ordering variability for a large number of accessions, or analyzing genetic relationships among breeding materials. Multivariate analytical techniques, which simultaneously analyze multiple measurements for each individual studied, are widely used in analysis of genetic diversity, irrespective of the dataset (morphological, biochemical, or molecular markers) (Mohammadi \& Prasanna, 2003). However, few rubber tree studies, such as those in Brazil by Paiva (1994), in Africa by Omokhafe \& Alika (2003), and in Asia by Mydin et al. (1992), have used these analyses.

The objective of the present work was to estimate the genetic variability from a small population of advanced rubber tree genotypes through univariate analyses and their genetic divergence using multivariate analysis, to indicate promising crosses.

\section{Materials and Methods}

Twenty-three rubber tree genotypes (clones) were evaluated for eight agronomic traits, in Jaú, São Paulo state, Brazil (22 ${ }^{\circ} 17^{\prime} \mathrm{S}, 48^{\circ} 34^{\prime} \mathrm{W}$ and $580 \mathrm{~m}$ altitude). Of the 23 genotypes, 22 belong to the IAC 400 series developed and selected at Instituto Agronômico (IAC), Campinas, SP, Brazil. One genotype (RRIM 600), obtained from the Research Institute of Malaysia (RRIM), was used as control, as shown in Table 1. The clones were budded on established GT1 clonal rootstocks in the nursery. One-and-a-half-year-old rootstock seedlings raised in nurseries were used to budgraft the clonal materials. The successful budgrafts were uprooted and planted in plastics bags. The experiment was planted in the field after the first flush of leaves. A randomized block design was used with three replicates and ten trees per plot, distributed in $8.0 \times 2.5 \mathrm{~m}$ spacing.

The traits related to vigor consisted of the mean girth annual increment before tapping, considering seven-year averages (GIB) and, after tapping, considering three-year averages (GIA), and girth growth increment in the third year of tapping (GGT).
The annual increment was calculated by subtracting the girths between consecutive years. In the first year, the girth was measured at $0.50 \mathrm{~m}$ above the budding callus using a caliper. Measurements were converted into annual girth growth values assuming that the trunk was cylindrical. After the first year, a tape was used to measure the girths at $1.20 \mathrm{~m}$ above the budding callus.

The studied variables related to rubber yield consisted of the general mean of dry rubber yield in the three years of yielding (RYF), mean of dry rubber yield in the third year of yielding (RYT) and mean tapping yield index (YI). Yield data collection started when the rubber trees were seven years old, with girths greater than $45 \mathrm{~cm}$.

Yield data was recorded on normal tapping days. The latex was collected in individual plastic cups for each tree and coagulated by adding $2 \%(\mathrm{v} / \mathrm{v})$ acetic acid solution, with stirring, to the cup once the latex flow

Table 1. Parentages of the genotypes studied.

\begin{tabular}{lll}
\hline $\mathrm{N}^{\mathrm{o}}$ & Genotype & \multicolumn{1}{c}{ Parentage } \\
\hline 1 & IAC 400 & GT 711 x RRIM 600 (Tjir 1 x PB 86) \\
2 & IAC 401 & RRIM 600 (Tjir 1 x PB 86) ill \\
3 & IAC 402 & GT 711 ill. \\
4 & IAC 403 & GT 711 ill. \\
5 & IAC 404 & PB 5/63 (PB 56 x PB 24) x AVROS 636 \\
6 & IAC 405 & Tjir 1 x RRIM 623(PB 49 x Pil B 84). \\
7 & IAC 406 & IAN 873 (PB 86 x FA 1717) x RRIM 600 \\
& & (Tjir 1 x PB 86) \\
8 & IAC 407 & RRIM 600 (Tjir 1 x PB 86) ill. \\
9 & IAC 408 & RRIM 513 (Pil B 16 x Pil A 44) ill. \\
10 & IAC 409 & Fx 2784 (F 4542 1 x AVROS 363)ill. \\
11 & IAC 410 & PB 86 x PB 235[PB 5/51 (PB 56 x PB 24) \\
& & x PB S/78 (PB 49 x PB 250)]. \\
12 & IAC 411 & GT 711 ill. \\
13 & IAC 412 & IAN 873 (PB 86 x FA 1717) x GT 711 \\
14 & IAC 413 & IAN 873 (PB 86 x FA 1717) ill. \\
15 & IAC 414 & IAC 126 [Fx 25 (F 351 x AVROS 49) x Tjir 1] ill. \\
16 & IAC 416 & RRIM 600 (Tjir 1 x PB 86) ill. \\
17 & IAC 417 & RRIM 600 (Tjir 1 x PB 86) ill. \\
18 & IAC 418 & RRIM 600 (Tjir 1 x PB 86) ill. \\
19 & IAC 420 & IAN 873 (PB 86 x FA 1717) ill. \\
20 & IAC 421 & IAC 157 [Fx 505(F 4542 (1) x AVROS 363) \\
& & x Fx 25 (F 351 x AVROS 49)] ill. \\
21 & IAC 422 & RRIM 513 (Pil B 16 x Pil A 44) ill. \\
22 & IAC 423 & IAC 90 [RRIM 507(Pil B 84 x Pil A 44) x Fx \\
& & 25(F 351 x AVROS 49)] ill. \\
23 & RRIM 600 & Tjir 1 x PB 86 \\
\hline
\end{tabular}

(1) Primary clone of Hevea benthamiana. Amazonian clones ( $\mathrm{F}=\mathrm{Ford}$, $\mathrm{FA}=$ Ford Acre, $\mathrm{Fx}=$ Ford crossbred, $\mathrm{IAN}=$ Instituto Agronômico do Norte); Clone from the State of São Paulo (IAC= Instituto Agronômico de Campinas); Asian clones (AVROS $=$ Algemene Vereniging Rubberplanters Oostkust Sumatra, Indonesia; GT= Godang Tapen, Indonesia; PB= Prang Besar, Malaysia; Pil= Pilmoor, Malaysia; RRIM= Rubber Research Institute of Malaysia, Malaysia; Tjir= Tjirandji, Indonesia); ill., illegitimate clone, obtained from open pollination. 
had stopped. The coagulated rubber in each cup was made into a "biscuit", which was dried for about 30 days by hanging on a wire tied to the tree from which it had been extracted. After drying, each rubber biscuit was weighed, and the data for each tree recorded. Then, the total annual weight yielded per tree was divided by the number of biscuits, and the data was expressed in grams of dry rubber per tapping per tree. For the trial, the tapping system $1 / 2 \mathrm{~S} \mathrm{~d} / 45 \mathrm{~d} / 711 \mathrm{~m} / \mathrm{y}$ ET $2.5 \%$ Pa10/y: tapping in half spiral $(1 / 2 \mathrm{~S})$, at 4-day tapping intervals $(\mathrm{d} / 4), 5$ days a week $(5 \mathrm{~d} / 7)$, for 11 months a year $(11 \mathrm{~m} / \mathrm{y})$, stimulated by $2.5 \%$ ethefon, applied with a paint brush on the tapping panel $(\mathrm{Pa}), 10$ times a year $(10 / y)$ was used.

The mean yield index (YI) was obtained as follows: $\mathrm{YI}=($ dry rubber yield in the third year)/(girth growth value in the third year of yielding).

The studied variables associated to the latex system consisted of bark thickness (BT) and number of latex vessel rings contained in the bark (NLV). In the seventh year, simultaneously with the opening of the tapping panel, samples of virgin bark were taken $1 \mathrm{~m}$ above the budding callus using an extractor. Bark samples were preserved in $70 \%$ ethanol and stored at $5^{\circ} \mathrm{C}$. Measurements were taken with a caliper, and means were expressed in millimeters. Paraffin-embedded bark samples were sliced with a microtome. Bark sections $(125 \mu \mathrm{m})$ were dehydrated in $90 \%$ ethanol and stained with Sudan III. Latex vessel rings were counted in longitudinal-radial histological samples using a light microscope at 10x magnification.

Univariate analysis was carried out on the data, and the means were compared by the Scott and Knott (1974) test. The multivariate analysis was based on eight agronomic traits.

The plot means of each character were used for the analysis of variance. The genotype means and effects were fixed, while the remaining data were considered random. In the analysis of variance, the estimated variation components were the genotypic $\left(\hat{\mathrm{V}}_{\mathrm{g}}\right)$ and environmental $\left(\hat{\mathrm{V}}_{\mathrm{c}}\right)$ variances. The coefficients of genetic $\left(\hat{C}_{\mathrm{g}} \%=100 . \hat{\mathrm{V}}_{\mathrm{g}} / \overline{\mathrm{x}}\right)$ and environmental $\left(\hat{C} V_{g} \%\right)$ variation were estimated, from which $\bar{x}$ is the overall mean of each character (descriptor).

The variation index $(\theta)$ as $\theta=\hat{\mathrm{C}} \mathrm{V}_{\mathrm{g} /} \hat{\mathrm{C}} \mathrm{V}_{\mathrm{e}}$ (Vencovsky, 1987) was used to estimate the genetic variability of the traits evaluated for the 23 genotypes. The variation index represents the ratio between the coefficient of genetic variation and the coefficient of environmental variation.

Genetic divergence among the genotypes was estimated by multivariate statistical analyses. Initially, the dissimilarity among genotypes was estimated using the Mahalanobis generalized distance, described by Cruz \& Carneiro (2003) as: $\mathrm{D}_{\mathrm{ii}}^{2}=\delta^{\prime} \psi^{-1} \delta$, in which: $\mathrm{D}_{\mathrm{ii}}^{2}$ is the Mahalanobis generalized distance among genotypes $i$ and $i^{\prime} ; \psi$ is the variance matrix and residual covariances; $\delta^{\prime}=\left[\begin{array}{llll}d_{1} & d_{2} & \ldots & d_{v}\end{array}\right]$, in which $d_{j}=Y_{i j}-Y_{i^{\prime} j}$; $Y_{i j}$ is the mean of the $i^{\text {th }}$ genotype in relation to the $j^{\text {th }}$ variable.

The Tocher optimization method was used for genotype clustering analysis. In the analysis of canonical variables, the divergence was visualized by graphic dispersion of the first variables. The relative contribution of each descriptor to genetic diversity was quantified using Singh's (1981) criterion. By this criterion, traits showing lower variability or represented by others are considered of minor importance.

The Genes software (Cruz, 2006) was used for all statistical analyses.

\section{Results and Discussion}

The genotype effects were significant $(\mathrm{p} \leq 0.01)$ for GIB, RYT, RYF, GGT, YI and BT traits, and for GIA and BT $(p \leq 0.05)$. This variability is an essential condition for a breeding program, indicating the possibility of selection between genotypes.

The estimates of genetic variance $\left(\hat{\mathrm{V}}_{\mathrm{g}}\right)$, environmental variance $\left(\hat{\mathrm{V}}_{\mathrm{e}}\right)$, coefficients of genetic variation $\left(\mathrm{CV}_{\mathrm{g}} \%\right)$, coefficients of experimental variation $\left(\mathrm{CV}_{\mathrm{e}} \%\right)$ and the variation indexes $(\theta)$ are shown in Table 2 . Knowledge of variation and heritability of the characters of interest is the basis upon which a well-designed Hevea breeding program should be based (Gonçalves et al., 2009). The coefficients of genetic variation $\left(\mathrm{CV}_{\mathrm{g}} \%\right)$ of the traits associated with yield (RYT, RYF and YI) were higher than those related to vigor (GIB, GIA and GGT). These results agreed with previous studies of rubber tree clones (Gonçalves et al., 2007) and progenies (Costa et al., 2000a, 2000b; Gonçalves et al., 2004) and indicated that the rubber production improvement program can be continued. The environmental variation coefficients varied from $6.58 \%$ (GGT) to $17.70 \%$ (RYT). Considering the criterion of Pimentel-Gomes (1987), the coefficients of environmental variation 
Table 2. Estimates of genetic variance $\left(\hat{\mathrm{V}}_{\mathrm{g}}\right)$, environmental variance $\left(\hat{\mathrm{V}}_{\mathrm{e}}\right)$, coefficients of genetic variation $\left(\hat{\mathrm{C}} \mathrm{V}_{\mathrm{g}}\right)$, coefficients of environmental variation $\left(\hat{\mathrm{C}} \mathrm{V}_{\mathrm{e}}\right)$ and variation index $(\hat{\theta})$ evaluated in 22 rubber tree genotypes (clones) and a control selected in the Brazilian Hevea breeding program.

\begin{tabular}{lccccc}
\hline Trait $^{(1)}$ & $\hat{V}_{\mathrm{g}}$ & $\hat{\mathrm{V}}_{\mathrm{e}}$ & $\hat{\mathrm{C}} \mathrm{V}_{\mathrm{g}}$ & $\hat{\mathrm{C}} \mathrm{V}_{\mathrm{e}}$ & $\hat{\theta}^{(2)}$ \\
\hline RYT & 265.3312 & 38.1290 & 26.9621 & 17.7030 & 1.5230 \\
RYF & 124.7577 & 15.9934 & 19.8873 & 12.3334 & 1.6125 \\
YI & 339.4501 & 51.2076 & 17.7017 & 11.9084 & 1.4865 \\
\hline \multicolumn{5}{c}{ Vigor } \\
GIB & 0.3623 & 0.0886 & 10.4147 & 8.9227 & 1.1672 \\
GIA & 0.1904 & 0.1487 & 9.6280 & 14.7361 & 0.6534 \\
GGT & 23.8463 & 4.2180 & 9.0299 & 6.5778 & 1.3728 \\
\hline \multicolumn{5}{c}{ Latex system } \\
BT & 0.1613 & 0.0488 & 7.2800 & 6.9350 & 1.0500 \\
NLV & 0.5299 & 0.4438 & 5.5404 & 8.7815 & 0.6309 \\
\hline
\end{tabular}

${ }^{(1)} \mathrm{RYT}$, mean dry rubber yield in the third year of yielding ( $\mathrm{g}$ per tapping per tree); RYF, mean of the means of dry rubber yield in the first three years of yielding ( $\mathrm{g}$ per tapping per tree); YI, yield index for three years $\left(\mathrm{g} \mathrm{cm}^{-1}\right.$ per tapping per tree), it refers to yield:girth ratio; GIB, mean girth growth increment before tapping $(\mathrm{cm})$; GIA, mean girth growth increment after tapping (cm); GGT, girth growth increment in the third year of tapping $(\mathrm{cm})$; BT, bark thickness (mm); NLV, number of latex vessel rings (unit). (2) $\hat{\theta}=\hat{\mathrm{C}} \mathrm{V}_{\mathrm{g}} / \hat{\mathrm{C}} \mathrm{V}_{\mathrm{e}}$. were low for GGT, BT, GIB and BT, indicating good experimental precision. For GIA, RYT, RYF and YI, the coefficients of environmental variation were average. The variation index $\theta$, a parameter that helps to detect the genetic variability of the population, was estimated for the eight variables studied. Values were higher than 1 for GIB, RYT, RYF, GGT, YI and BT. According to Vencosvsky (1987) in a study on a selection of corn progenies, when $\theta$ is equal to or higher than 1 , conditions are highly favorable for selection.

The highest girth growth increments, considering seven-year averages, were observed before tapping in the IAC $402(7.07 \mathrm{~cm})$, IAC $412(6.75 \mathrm{~cm})$ and IAC $413(6.66 \mathrm{~cm})$ genotypes, which were all significantly higher than the experimental control (Table 3 ). For girth growth increments after tapping, considering three-year averages, the highest values were found in the IAC 409 $(5.43 \mathrm{~cm}), \operatorname{IAC} 412(5.42 \mathrm{~cm})$ and IAC $402(5.36 \mathrm{~cm})$ genotypes, none of which was significantly higher than the control. The average girth growth increment before tapping was higher than after tapping, for all

Table 3. Agronomic traits evaluated in twenty-two rubber tree genotypes of the IAC 400 series and in the control (RRIM $600)$, selected in the Brazilian Hevea breeding program $^{(1)}$.

\begin{tabular}{|c|c|c|c|c|c|c|c|c|}
\hline Genotype & $\begin{array}{l}\text { GIB } \\
(\mathrm{cm})\end{array}$ & $\begin{array}{l}\text { GIA } \\
(\mathrm{cm})\end{array}$ & $\begin{array}{l}\text { GGT } \\
(\mathrm{cm})\end{array}$ & $\begin{array}{c}\text { RYT } \\
\text { (g per tapping per tree) }\end{array}$ & $\begin{array}{c}\text { RYF } \\
\text { (g per tapping per tree) }\end{array}$ & $\begin{array}{c}\text { YI } \\
\left(\mathrm{g} \mathrm{cm}^{-1} \text { per tapping per tree }\right)\end{array}$ & $\begin{array}{c}\text { BT } \\
(\mathrm{mm})\end{array}$ & NLV \\
\hline IAC 400 & $6.12 \mathrm{a}$ & $5.03 a$ & $57.94 b$ & $101.69 \mathrm{a}$ & $87.10 \mathrm{a}$ & $150.49 \mathrm{a}$ & $5.28 b$ & $12.31 \mathrm{~b}$ \\
\hline IAC 401 & $5.85 \mathrm{a}$ & $3.59 b$ & $51.69 \mathrm{c}$ & $85.65 \mathrm{a}$ & $64.80 \mathrm{c}$ & $125.31 b$ & $5.24 b$ & $12.28 b$ \\
\hline IAC 402 & $7.07 \mathrm{a}$ & $5.36 \mathrm{a}$ & $65.62 \mathrm{a}$ & $68.69 \mathrm{~b}$ & $57.32 \mathrm{~d}$ & 87.72 & $5.67 \mathrm{a}$ & $13.69 \mathrm{a}$ \\
\hline IAC 403 & $5.13 b$ & $4.11 \mathrm{~b}$ & $48.20 \mathrm{c}$ & $71.18 \mathrm{~b}$ & $56.19 d$ & $116.57 b$ & $5.34 \mathrm{~b}$ & $12.83 b$ \\
\hline IAC 404 & $6.01 \mathrm{a}$ & $3.74 b$ & $53.25 \mathrm{c}$ & $57.85 \mathrm{c}$ & $52.54 d$ & $99.02 \mathrm{c}$ & $6.11 \mathrm{a}$ & $14.39 \mathrm{a}$ \\
\hline IAC 405 & $5.53 b$ & $4.64 a$ & $52.61 \mathrm{c}$ & $75.48 b$ & $68.42 \mathrm{c}$ & $130.75 \mathrm{a}$ & $5.66 a$ & $13.44 \mathrm{a}$ \\
\hline IAC 406 & $6.18 \mathrm{a}$ & $4.41 b$ & $56.50 \mathrm{~b}$ & $75.73 b$ & $75.46 \mathrm{~b}$ & $133.61 \mathrm{a}$ & $5.09 \mathrm{~b}$ & $11.75 b$ \\
\hline IAC 407 & $5.18 b$ & $4.77 \mathrm{a}$ & $50.53 c$ & $37.27 \mathrm{~d}$ & $39.93 \mathrm{e}$ & $78.93 \mathrm{c}$ & $5.41 b$ & $13.67 \mathrm{a}$ \\
\hline IAC 408 & $4.47 b$ & $4.31 \mathrm{~b}$ & $44.27 \mathrm{c}$ & $43.18 \mathrm{~d}$ & $42.80 \mathrm{e}$ & $96.58 \mathrm{c}$ & $5.50 \mathrm{~b}$ & $12.50 \mathrm{~b}$ \\
\hline IAC 409 & $4.86 \mathrm{~b}$ & $5.43 a$ & $51.04 \mathrm{c}$ & $63.58 \mathrm{c}$ & $47.29 \mathrm{e}$ & $93.06 \mathrm{c}$ & $4.60 \mathrm{~b}$ & $12.33 b$ \\
\hline IAC 410 & $5.33 b$ & $4.00 \mathrm{~b}$ & $49.27 \mathrm{c}$ & $62.71 \mathrm{c}$ & $60.33 c$ & $122.46 b$ & $5.68 \mathrm{a}$ & $14.67 \mathrm{a}$ \\
\hline IAC 411 & $6.59 \mathrm{a}$ & $4.73 a$ & $60.33 b$ & $90.00 \mathrm{a}$ & $71.39 \mathrm{~b}$ & $118.51 \mathrm{~b}$ & $5.22 b$ & $11.71 \mathrm{~b}$ \\
\hline IAC 412 & $6.75 a$ & $5.42 \mathrm{a}$ & $63.48 \mathrm{a}$ & $59.79 \mathrm{c}$ & $61.52 \mathrm{c}$ & $96.81 \mathrm{c}$ & $5.79 a$ & $14.17 \mathrm{a}$ \\
\hline IAC 413 & $6.66 a$ & $4.23 b$ & $59.29 b$ & $44.32 d$ & $60.25 \mathrm{c}$ & $101.62 \mathrm{c}$ & $4.92 b$ & $12.33 b$ \\
\hline IAC 414 & $5.50 \mathrm{~b}$ & $5.36 \mathrm{a}$ & $54.58 \mathrm{c}$ & $54.92 \mathrm{c}$ & $60.53 c$ & $110.87 \mathrm{~b}$ & $5.00 \mathrm{~b}$ & $12.50 \mathrm{~b}$ \\
\hline IAC 416 & $5.42 b$ & $4.40 \mathrm{~b}$ & $51.19 \mathrm{c}$ & $46.98 \mathrm{~d}$ & $40.82 \mathrm{e}$ & $79.83 c$ & $6.24 \mathrm{a}$ & $13.00 \mathrm{~b}$ \\
\hline IAC 417 & $5.25 b$ & $4.29 b$ & $49.64 c$ & $70.83 b$ & $50.11 \mathrm{~d}$ & $100.90 \mathrm{c}$ & $5.33 b$ & $12.33 b$ \\
\hline IAC 418 & $6.37 \mathrm{a}$ & $5.32 \mathrm{a}$ & $60.52 b$ & $48.56 \mathrm{~d}$ & $50.52 d$ & $82.74 c$ & $5.38 b$ & $13.18 b$ \\
\hline IAC 420 & $5.01 \mathrm{~b}$ & $4.00 \mathrm{~b}$ & $47.10 \mathrm{c}$ & $43.72 d$ & $54.19 \mathrm{~d}$ & $115.40 \mathrm{~b}$ & $5.11 \mathrm{a}$ & $12.20 \mathrm{~b}$ \\
\hline IAC 421 & $6.10 \mathrm{a}$ & $4.18 b$ & $55.22 \mathrm{c}$ & $36.17 d$ & $40.56 \mathrm{e}$ & $73.85 \mathrm{c}$ & $5.81 \mathrm{a}$ & $14.90 \mathrm{a}$ \\
\hline IAC 422 & $5.77 b$ & $4.66 \mathrm{a}$ & $54.39 \mathrm{c}$ & $52.16 \mathrm{c}$ & $52.37 \mathrm{~d}$ & $96.39 \mathrm{c}$ & $5.98 b$ & $14.21 \mathrm{a}$ \\
\hline IAC 423 & $6.32 \mathrm{a}$ & $3.59 b$ & $55.00 \mathrm{c}$ & $43.66 \mathrm{~d}$ & $51.39 \mathrm{~d}$ & $93.50 \mathrm{c}$ & $6.48 \mathrm{a}$ & $14.68 \mathrm{a}$ \\
\hline RRIM 600 & $5.45 \mathrm{~b}$ & $4.67 \mathrm{a}$ & $52.15 \mathrm{c}$ & $55.40 \mathrm{c}$ & $45.93 \mathrm{e}$ & $88.96 \mathrm{c}$ & $6.03 \mathrm{a}$ & $13.11 \mathrm{~b}$ \\
\hline
\end{tabular}

${ }^{(1)}$ Means followed by same letter, in the columns, do not differ significantly by the Scott \& Knott (1974) test at 5\% probability. GIB, mean girth growth increment before tapping; GIA, mean girth growth increment after tapping; GGT, girth growth increment in the third year of tapping; RYT, mean yield of dry rubber in the third year of yielding, RYF, mean of the means of dry rubber yield in the three first years of yielding; YI, yield index for three years; BT, bark thickness; NLV, number of latex vessel rings. 
genotypes except IAC 409. In general, girth growth is lower after than before tapping. In the after-tapping phase, the source-drain relationship is altered with the carbohydrate reserves used for latex regeneration, and girth growth is reduced (Castro, 2000).

The IAC 400 genotype showed the highest dry rubber yield in the third year of yielding (RYT) and also the highest general mean of dry rubber yield, during the three years of yielding (RYF), differing significantly from all other genotypes. Gonçalves et al. (2007) reported high performance of this genotype in annual assessments of dry rubber yield. IAC 400 performed better than the control (RRIM 600) for GIB, GGT and YI. The virgin bark thickness (BT) varied between $6.48 \mathrm{~cm}$ and $4.60 \mathrm{~cm}$ in the opening of the tapping panel. The highest and lowest values were observed in IAC 423 and IAC 409, respectively. These values were similar to those observed by Gonçalves et al. (2006 a). However, bark thickness was not significantly higher than the control, for any of the genotypes. Over one third of the genotypes had a higher average number of latex vessel rings than the control.

In the multivariate analysis, through $\mathrm{D}_{\mathrm{ii}}^{2}$, the highest divergence was observed between IAC 409 and IAC $423\left(D_{\mathrm{ii}^{\prime}}^{2}=61.45\right)$. It must be emphasized that IAC 409 has the Hevea benthamiana clone F 4542 in its ascendance, which may have increased its genetic diversity (Rieserberg, 1997). The lowest divergence was observed between IAC 416 and RRIM $600\left(\mathrm{D}_{\mathrm{ii}}^{2}=2.57\right)$. This small value was due to the fact that RRIM 600 is the female parent of IAC 416 (Table 1).

When comparing the performance of the genotypes (Table 3), IAC 409 and IAC 423 - the most divergent

Table 4. The fifteen most divergent pairs of genotypes according to the Mahalanobis generalized distance $\left(\mathrm{D}_{\mathrm{ii}}^{2}\right)$ estimated for 22 rubber tree genotypes of the IAC 400 series, selected in the Brazilian Hevea breeding program.

\begin{tabular}{|c|c|c|c|}
\hline Order & $\mathrm{D}_{\mathrm{ii}^{\prime}}^{2}$ & Pairs of Genotypes & Parents \\
\hline \multirow{2}{*}{$1^{\underline{0}}$} & \multirow{2}{*}{61.4544} & IAC $409(10)$ & Fx $2784\left(\mathrm{~F} 4542^{(1)}\right.$ x AVROS 363)ill. \\
\hline & & IAC $423(22)$ & IAC 90 [RRIM 507(Pil B 84 x Pil A 44) x Fx 25(F 351 x AVROS 49) ill. \\
\hline \multirow{2}{*}{$2^{\underline{o}}$} & \multirow{2}{*}{59.4175} & IAC $413(14)$ & IAN 873 (PB 86 x FA 1717) ill. \\
\hline & & IAC 417 (17) & RRIM 600 (Tjir 1 x PB 86) ill. \\
\hline \multirow{2}{*}{$3^{\circ}$} & \multirow{2}{*}{56.1916} & IAC $400(1)$ & GT 711 x RRIM 600 (Tjir 1 x PB 86) \\
\hline & & IAC $421(20)$ & IAC 157 [Fx 505(F4542(1) x AVROS 363) x Fx 25 (F351 x AVROS 49) ill. \\
\hline \multirow{2}{*}{$4^{-0}$} & \multirow{2}{*}{54.5172} & IAC $400(1)$ & GT 711 x RRIM 600 (Tjir 1 x PB 86) \\
\hline & & IAC $416(16)$ & RRIM 600 (Tjir 1 x PB 86) ill. \\
\hline \multirow{2}{*}{$5^{\circ}$} & \multirow{2}{*}{52.964} & IAC $402(3)$ & GT 711 ill. \\
\hline & & IAC 420 (19) & IAN 873 (PB 86 x FA 1717) ill. \\
\hline \multirow{2}{*}{$6^{\underline{0}}$} & \multirow{2}{*}{52.8116} & IAC $409(10)$ & Fx $2784\left(\right.$ F 4542 $2^{(1)}$ x AVROS 363) ill. \\
\hline & & IAC $413(14)$ & IAN 873 (PB 86 x FA 1717) ill. \\
\hline \multirow{2}{*}{$7^{\mathrm{o}}$} & \multirow{2}{*}{52.5762} & IAC $402(3)$ & GT 711 ill. \\
\hline & & IAC 408 (9) & RRIM 513 (Pil B 16 x Pil A 44) ill. \\
\hline \multirow{2}{*}{$8^{\underline{o}}$} & \multirow{2}{*}{49.8651} & IAC $401(2)$ & RRIM 600 (Tjir 1 x PB 86) ill, \\
\hline & & IAC 413(14) & IAN 873 (PB 86 x FA 1717) ill \\
\hline \multirow{2}{*}{$9^{-}$} & \multirow{2}{*}{49.8019} & IAC $400(1)$ & GT 711 x RRIM 600 (Tjir 1 x PB 86) \\
\hline & & IAC $409(10)$ & IAC 90 [RRIM 507(Pil B 84 x Pil A 44) x Fx 25(F 351 x AVROS 49) ill. \\
\hline \multirow{2}{*}{$10^{\circ}$} & \multirow{2}{*}{48.0781} & IAC $400(1)$ & GT 711 x RRIM 600 (Tjir 1 x PB 86) \\
\hline & & IAC $423(22)$ & IAC 90 [RRIM 507(Pil B 84 x Pil A 44) x Fx 25(F 351 x AVROS 49) ill. \\
\hline \multirow{2}{*}{$11^{\circ}$} & \multirow{2}{*}{47.9772} & IAC $400(1)$ & IAC 90 [RRIM 507(Pil B 84 x Pil A 44) x Fx 25(F 351 x AVROS 49) ill. \\
\hline & & IAC $407(8)$ & IAN 873 (PB 86 x FA 1717) x GT 711 \\
\hline \multirow{2}{*}{$12^{\mathrm{o}}$} & \multirow{2}{*}{47.9441} & IAC 400 (1) & IAC 90 [RRIM 507(Pil B 84 x Pil A 44) x Fx 25(F 351 x AVROS 49) ill. \\
\hline & & IAC 408 (9) & RRIM 513 (Pil B 16 x Pil A 44) ill. \\
\hline \multirow{2}{*}{$13^{\underline{0}}$} & \multirow{2}{*}{46.7059} & IAC $411(12)$ & GT 711 ill. \\
\hline & & IAC 420 (19) & IAN 873 (PB 86 x FA 1717) ill. \\
\hline \multirow{2}{*}{$14^{\circ}$} & \multirow{2}{*}{46.5931} & IAC $400(1)$ & IAC 90 [RRIM 507(Pil B 84 x Pil A 44) x Fx 25(F 351 x AVROS 49) ill. \\
\hline & & IAC 402 (3) & GT 711 ill. \\
\hline \multirow{2}{*}{$15^{\mathrm{o}}$} & \multirow{2}{*}{45.8442} & IAC $412(13)$ & IAN 873 (PB 86 x FA 1717) ill. \\
\hline & & IAC $417(17)$ & RRIM 600 (Tjir 1 x PB 86) ill. \\
\hline
\end{tabular}


pair (Table 4) - showed equal or better performance than the experimental control for almost all traits, except for BT (IAC 409) and GIA and RYT (IAC 423). Nevertheless, in the least divergent pair formed by IAC 416 and the control RRIM 600, IAC 416 did not show better performance than the control for any of the traits studied and, therefore, it is not an interesting alternative for breeding. IAC 400 was prominent in divergence and had better performance than the control for GIB, GGT, RYT, RYF and YI, allying divergence to good performance, especially regarding traits related to dry rubber yield. In crossbreeding, performance should be taken into consideration in addition to genetic divergence (Paiva, 1994; Cruz \& Carneiro, 2003; Elias et al., 2007).

The fifteen most divergent pairs of genotypes, identified through $\mathrm{D}_{\mathrm{ii}}^{2}$, are suggested for crossbreeding (Table 4). Genotypes of the IAC 400 series have already gone through a selection cycle (Gonçalves et al., 2007) and, therefore, contain traits of interest. With breeding between superior genotypes, a combination of favorable alleles in the genes that contribute to the traits of interest is expected. The rubber tree is allogamous; thus superior and divergent parents enable greater variability in segregating progenies. Consequently, there is a greater chance for obtaining progenies that are superior to the parents with genotypes that can be fixed by asexual propagation.

Table 5. Clustering by the Tocher method of 22 rubber tree genotypes of the IAC 400 series and the control (RRIM 600) selected in the breeding program of the Instituto Agronômico (IAC), based on dissimilarity estimated by the Mahalanobis generalized distance obtained from the eight quantitative descriptors.

\begin{aligned} & \hline Group \multicolumn{1}{c}{ Genotype } \\ & \hline 1 IAC 416, RRIM 600, IAC 404, IAC 422, IAC 421, IAC 407 \\ & 2 IAC 405, IAC 410, IAC 403 \\ & 3 IAC 412, IAC 418, IAC 402 \\ & 4 IAC 401, IAC 417 \\ & 5 IAC 413, IAC 414, IAC 406 \\ & 6 IAC 420 \\ & 7 IAC 400 \\ & 8 IAC 423 \\ & 9 IAC 411 \\ & 10 IAC 408 \\ & 11 IAC 409 \\ & \hline\end{aligned}

The Tocher method, applied to the dissimilarity matrix obtained from the Mahalanobis generalized distance, distinguished 11 groups (Table 5), which indicated that although these genotypes are a result of selection in a breeding program, they still maintain high genetic diversity.

The descriptors that showed the highest contribution (S.j\%) to genetic divergence were RYT $(24.45 \%)$, RYF $(23.57 \%)$ and GIB (17.36\%). It can be inferred that, for these traits, the contribution is genetically related, since it was verified that $\theta>1$ (Table 2). According to the present study, the yield-related traits (RYT, RYF) showed high contribution for divergence and high genetic variability. Increased rubber yield is the primary objective of rubber tree breeding and, in previous studies, it has shown high genetic variability (Costa et al., 2002; Gonçalves et al., 2006b). However, the descriptors that presented a lower contribution to genetic divergence, YI (1.97\%), NLV (2.84\%) and GGT $(6.37 \%)$ can be considered of little importance, since they can be represented by other descriptors. According to Singh's criteria (1981), characters with low variability that are represented by others are of little contribution. High phenotypic correlations were found between YI and RYF $\left(\mathrm{r}=0.8907^{* *}\right)$, YI and RYT $\left(\mathrm{r}=0.7758^{* *}\right)$, NLV and BT $\left(r=0.7336^{* *}\right)$, and GIB and GGT $\left(r=0.9418^{* *}\right)$. The coefficients of genetic correlation were 0.8969 , $0.7812,0.8463$ and 0.9727 , respectively. Concerning variability, Gonçalves et al. (2004) reported the lack of a significant genotypic or phenotypic correlation between growth vigor and the total number of latex vessel rings, which indicates that there would be a low genetic gain for these traits, even if selection were undertaken for only one trait.

The first two canonical variables accumulated $56.77 \%$ of the total variation, with $75.16 \%$ for the first three and $87.93 \%$ for the first four. According to Cruz \& Carneiro (2003), when the first canonical variables explain around $80 \%$ of the total variation, the analysis of the genetic diversity through graphic dispersion is satisfactory. Figure 1 shows the tridimensional graphic representation, in which $75.16 \%$ of the variation is accumulated. The distance among the 15 pairs of the most divergent genotypes, listed in Table 3, can be visualized, especially the distance of IAC 400 (1), which is among the 


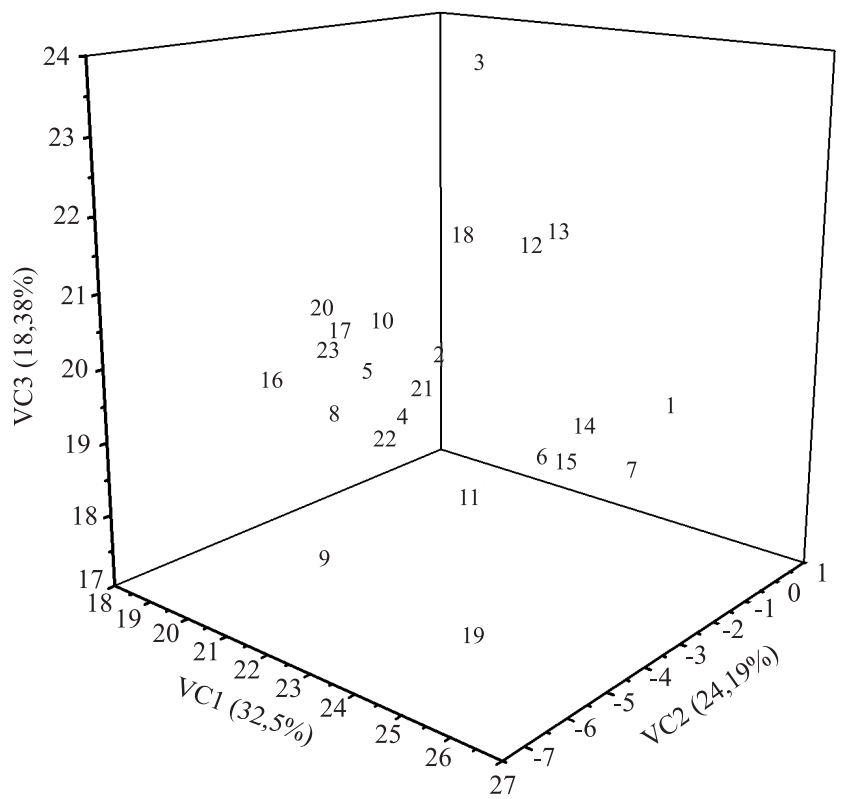

Figure 1. Graphic dispersion of the 23 rubber tree genotypes in relation to the first three canonical variables (VC) obtained from the eight quantitative descriptors. See Table 1 for identification of the genotypes.

most divergent genotypes. Therefore, there was consistency between the graphic visualization and the identification of the divergent genotypes.

\section{Conclusions}

1. The highest genetic variability is observed in rubber yield-related traits, which also contribute the most to genetic divergence.

2. The small population of rubber tree clones shows potential for selection and may be used to continue a rubber tree breeding program with emphasis on yield.

3. Of this population, only IAC 400 allied genetic divergence to high yield performance and vigor in the pre-tapping period.

4. The most divergent rubber tree genotypes identified in this study are the most indicated for crossbreeding.

\section{Acknowledgements}

To Fundação de Amparo à Pesquisa do Estado de São Paulo (Fapesp) and to Conselho Nacional de Desenvolvimento Científico e Tecnológico (CNPq), for financial support.

\section{References}

CASTRO, P.R.C. Bases fisiológicas da produção do látex e da estimulação de Hevea brasiliensis Muell. Arg. In: BERNARDES M. S. (Ed). Sangria da seringueira. Piracicaba: Esalq, 2000. p.45-63.

CHANDRASEKHAR, T.R.; MARATTUKALAM J.G.; MERCYKUTTY, V.C.; PRIYADARSHAN, P.M. Age of yield stabilization and its implications for optimizing selection and shortening breeding cycle in rubber (Hevea brasiliensis). Euphytica, v.156, p.67-75, 2007.

COSTA, R.B.; RESENDE, M.D.V.; ARAUJO, A.J.; GONÇALVES, P.S.; BORTOLETTO, N. Seleção combinada univariada e multivariada aplicada ao melhoramento genético da seringueira. Pesquisa Agropecuária Brasileira, v.35, p.381-388, 2000a.

COSTA, R.B.; RESENDE, M.D.V.; ARAUJO, A.J.; GONÇALVES, P.S.; SILVA, M.A. Maximization of genetic gain in rubber tree (Hevea) breeding with effective size restriction. Genetic and Molecular Biology, v.23, p.457-462, 2000b.

COSTA, R.B.; RESENDE, M.D.V.; GONÇALVES, P.S.; SILVA, M.A. Individual multivariate REML/BLUP in the presence of genotype $\mathrm{x}$ environment interaction in rubber tree (Hevea) breedings. Crop Breeding Applied Biotechnology, v.2, p.131-140, 2002.

CRUZ, C.D. (Ed.). Programa GENES: multivariate analysis and simulation. Viçosa: UFV, 2006. 175p.

CRUZ, C.D.; CARNEIRO, P.C.S. (Ed.). Modelos biométricos aplicados ao melhoramento genético. Viçosa: UFV. 2003. 585p.

ELIAS, H.T.; VIDIGAL, M.C.G.; GONELA, A.; VOGT, G.A. Variabilidade genética em germoplasma tradicional de feijão-preto em Santa Catarina. Pesquisa Agropecuária Brasileira, v.42, p.1443-1449, 2007.

GONÇALVES, P.S.; AGUIAR, A.T.E.; COSTA, R.B.; GONÇALVES, E.C.P.; SCALOPPI-JUNIOR E.J.; BRANCO, R.B.F. Genetic variation and realized genetic gain from rubber tree improvement. Scientia Agricola, v.66, p.44-51, 2009.

GONÇALVES, P.S.; AGUIAR, A.T.E.; GOUVÊA, L.R.L. Expressão fenótípica de clones de seringueira na região noroeste do Estado de São Paulo. Bragantia, v.65, p.389-398, 2006 b.

GONÇALVES, P.S.; MARTINS, A.L.M.; BORTOLETTO, N.; SAES, L.A. Selection and genetic gains for juvenile traits in progenies of Hevea in São Paulo state, Brazil. Genetics and Molecular Biology, v.27, p.207-214, 2004.

GONÇALVES, P.S.; SILVA, M.A.; AGUIAR, A.T.E.; MARTINS, M.A.; SCALOPPI-JUNIOR, E.J.; GOUVÊA, L.R.L. Performance of new Hevea clones from IAC 400 series. Scientia Agricola. v.64, p.241-248, 2007.

GONÇALVES, P.S.; SILVA, M.A.; GOUVÊA, L.R.L.; SCALOPPI-JUNIOR, E.J. Genetic variability for girth growth and rubber yield in Hevea brasiliensis. Scientia Agricola, v.63, p.246-254, 2006a.

INTERNATIONAL RUBBER STUDY GROUP. Rubber statistical bulletin. Wembley: IRSG, 2009. v.63. 61p. Available at: $<$ http://www.rubberstudy.com>. Accessed on: 25 June 2009. 
MOHAMMADI, S.A.; PRASANNA, B.M. Analyses of genetic diversity in crop plants - salient statistics tools and considerations. Crop Science, v.43, p.1235-1248, 2003.

MYDIN, K.K.; GOPINATHAN, N; SETHURAJ, M.R.; SARASWATHY, P.; PANIKKAR O.N. Genetic divergence in Hevea brasiliensis. Indian Journal of Natural Rubber Research, v.5, p.120-126, 1992.

OMOKHAFE, K.O.; ALIKA, J.E. Phenetic relationship of rubber tree clones. Biologia Plantarum, v.46, p.217-222, 2003.

PAIVA, J.R. Divergência genética entre clones primários de seringueira. Pesquisa Agropecuária Brasileira, v.29, p.607-615, 1994.
PIMENTEL-GOMES, F. (Ed.). Curso de estatística experimental. São Paulo: Nobel, 1990. 465p.

RIESEBERG, L.H. Hybrid origins of plant species. Annual Review of Ecology and Systematics, v.28, p.359-389, 1997.

SINGH, D.A. The relative importance of characters affecting genetic divergence. Indian Journal of Genetics and Plant Breeding, v.41, p.237-245, 1981.

SCOTT, A.J.; KNOTT, M.A.A. A cluster analysis method for grouping means in the analysis of variance. Biometrics, v. 30, p.507-512, 1974.

VENCOVSKY, R. Herança quantitativa. In: PATERNIANI, E.; VIEGAS, G.P. (Ed.). Melhoramento e produção de milho. Campinas: Fundação Cargill, 1987. p.137-214.

Received on December 12, 2009 and accepted on January 5, 2010 